Tropical Journal of Pharmaceutical Research December 2015; 14 (12): 2269-2277

ISSN: $1596-5996$ (print); 1596-9827 (electronic)

(C) Pharmacotherapy Group, Faculty of Pharmacy, University of Benin, Benin City, 300001 Nigeria.

All rights reserved.

Available online at http://www.tjpr.org

Original Research Article

http://dx.doi.org/10.4314/tjpr.v14i12.17

\title{
Studies on Anti-Depressant Activity of Four Flavonoids Isolated from Apocynum venetum Linn (Apocynaceae) Leaf in Mice
}

\author{
Shao-Xiao Yan*, Jun-Lian Lang, Yan-Ying Song, Yu-Ze Wu, Meng-Han Lv, Xia \\ Zhao, Yan-Hong Liu and Chun-Yan Xu
}

Department of Integrated Traditional and Western Medicine, Beijing Huilongguan Hospital, Peking University, Beijing 100096, PR China

*For correspondence: Email: bjhlghyan@126.com

Received: 20 July 2015

Revised accepted: 28 October 2015

\begin{abstract}
Purpose: To investigate the anti-depressant activity of kaempferol, quercetin, kaempferol-3-O- $\beta-D$ glucose and quercetin-3-O- $\beta-D-$ glucose isolated from Apocynum venetum Linn. (Apocynaceae) leaf and their mechanisms of action.

Methods: The four flavonoids were isolated from Apocynum venetum leaf by chromatography. Mice were divided into vehicle, fluoxetine, kaempferol, quercetin, kaempferol-3-O- $\beta$-D-glucose and quercetin$3-O-\beta-D$-glucose groups $(n=10)$. Forced swimming (FST), tail suspension (TST) and locomotor activity (LAT) tests were used to evaluate the effects of the four flavonoids $(0.35 \mathrm{mM} / \mathrm{kg})$ on immobility time, monoamine neurotransmitters, viz, norepinephrine (NE), dopamine (DA) and 5-hydroxytryptamine (5$H T)$, as well as on the metabolite (5-HIAA) in mice brain and central nervous system (CNS) with the aid of video camera, HPLC-ECD and activity-monitoring system.

Results: The four flavonoids significantly $(p<0.05)$ reduced mice immobility time $(72.58-90.24 ; 52.58$ - $70.24 \mathrm{~s}), 5-H I A A$ levels (940.8 - 1244.7; 880.8 - $1164.1 \mathrm{ng} / \mathrm{g})$ and 5-HIAA/5-HT ratio (1.77 - 4.76; 1.83 - 4.16), but increased NE, DA and 5-HT levels (238.7 - 405.7, 308.4 - 528.1, 261.4 - 531.9; 243.9 423.6, 296.7 - 534.9, 279.8 - 481.4 $\mathrm{ng} / \mathrm{g}$ ) in FST and TST, compared with control group (146.18, 126.18 $\mathrm{s} ; 1363.4,1240.9 \mathrm{ng} / \mathrm{g} ; 7.43,6.16 ; 138.4,235.4,183.4$ and 143.7, 218.6, $201.4 \mathrm{ng} / \mathrm{g})$. The effects of the four flavonoids on the above indices were significant $(p<0.05)$ and positively related to their polarity. They had no CNS-stimulating effects in LAT.

Conclusion: The anti-depressant activities of the four flavonoids are positively related to their polarity, and the mechanisms may be due to increased NE, DA and 5-HT and reduced 5-HT metabolism.
\end{abstract}

Keywords: Kaempferol, Quercetin, Forced swimming test, Tail suspension test, Locomotor activity test, Neurotransmitters

Tropical Journal of Pharmaceutical Research is indexed by Science Citation Index (SciSearch), Scopus, International Pharmaceutical Abstract, Chemical Abstracts, Embase, Index Copernicus, EBSCO, African Index Medicus, JournalSeek, Journal Citation Reports/Science Edition, Directory of Open Access Journals (DOAJ), African Journal Online, Bioline International, Open-J-Gate and Pharmacy Abstracts

\section{INTRODUCTION}

Depression is a kind of mental disorders and its major symptoms include the reduced interest and pleasure, lowered mood and metabolic disorder of monoamine neurotransmitters in the central nervous system (CNS) [1]. World Health
Organization (WHO) predicted that depression will be the second most common disease in 2020 [2].

Apocynum venetum Linn. (Apocynaceae family) is widely distributed in many provinces of China such as Xinjiang, Gansu, Shandong and Hebei 
[3]. It's reported that $A$. venetum leaf has lots of pharmacological effects such as anti-oxidant [4,5], anti-hypertensive [6], anti-depressant [7] and anti-anxiety activities [8]. A series of studies [9-14] suggested that the active constituents of anti-depressant activity of $A$. venetum leaf are total flavonoids. The flavonoids of $A$. venetum leaf include tamarixetin, kaempferol, quercetin, hyperoside, trifolin, quercetin-3-O-(6"-Omalonyl)- $\beta$-D-glucose, kaempferol-3-O- $\beta$-Dglucose, quercetin-3-O- $\beta$-D-glucose, rutin, etc $[15,16]$. Although it is reported that quercetin and kaempferol have significant anti-depressant activities [17,18], differences in their antidepressant activities as well as possible mechanisms still need further investigation. Thus, the main aim of the present study was to evaluate the differences in the anti-depressant activities of quercetin, quercetin-3-O- $\beta$-Dglucose, kaempferol and kaempferol-3-O- $\beta$-Dglucose isolated from $A$. venetum leaf.

\section{EXPERIMENTAL}

\section{Plant material}

$A$. venetum leaves were purchased from Chinese herbal medicine market of Xian in 2013, identified by Jun-Lian Lang. A voucher specimen (voucher no. BJHLGH20130164) was stored in pharmacy department of Beijing Huilongguan Hospital for future reference.

\section{Chemicals and reagents}

Analytical grade ethanol, methanol, chloroform, petroleum ether, ethyl acetate, n-butyl alcohol and silica gel were obtained from Qingdao Haiyang Chemical Co., Ltd. (Qingdao, China) and Sephadex LH-20 was purchased from H\&E Co., Ltd (Beijing, China). HPLC grade methanol was purchased from Fisher (Fisher Scientific, Germany). Fluoxetine- $\mathrm{HCl}$ was obtained from Lilly (Lilly, USA, purity > $98 \%$ ). NE, DA, 5-HT, 5HIAA and dihydroxy-benzoic acid (DHBA) were obtained from Sigma (Sigma, USA, purity $>98$ $\%)$.

\section{Animals}

Male mice (20 $\pm 2 \mathrm{~g}$ ) were purchased from the SLRC Laboratory Animal Company (Shanghai, China). The animals were conditioned to standard laboratory conditions (12/12 h light /dark cycle at $25 \pm 1^{\circ} \mathrm{C}$ ) and had free access to food and water. All experiments were strictly in accordance with the international guidelines for care and use of laboratory animals [19]. The experiments were carried out with the approval of the Animal Care and Use Committee of Beijing Huilongguan Hospital (protocol no: BJHLGH ACUC2013).

\section{Extraction and isolation}

The air-dried $A$. venetum leaves $(10 \mathrm{~kg})$ were finely cut and extracted with $75 \%$ ethanol by percolation method at the speed of $20 \mathrm{~mL} / \mathrm{min}$. The $75 \%$ ethanol solvent was combined and concentrated under vacuum to afford a crude extract $(1.2 \mathrm{~kg})$, which was then suspended in hot water and successfully partitioned with petroleum ether, ethyl acetate and n-butyl alcohol. The ethyl acetate fraction $(180 \mathrm{~g})$ was subjected to column chromatography (CC) over silica gel $(74-149 \mu \mathrm{m})$, eluted with chloroformmethanol and chloroform-methanol-water to obtain nine fractions. Fraction $2(32.2 \mathrm{~g})$ was separated by CC over silica gel (chloroformmethanol) and purified on Sephadex LH-20 (chloroform-methanol) to provide compounds kaempferol $(98 \mathrm{mg})$ and quercetin $(173 \mathrm{mg})$. Fraction $5(28.9 \mathrm{~g})$ was separated by CC over silica gel (chloroform-methanol-water) and purified on Sephadex LH-20 (chloroformmethanol-water) to provide compounds kaempferol-3-O- $\beta$-D-glucose $(67 \mathrm{mg})$ and quercetin-3-O- $\beta$-D-glucose (173 mg). The structures of the four compounds were identified by nuclear magnetic resonance (NMR) data, compared with the existing literatures [15,16], and their purities were more than $98 \%$, verified by area normalization method of high performance liquid chromatography with electrochemical detector (HPLC-ECD). Their chemical structures are shown in Figure 1.

\section{Grouping and drug treatment}

Mice were randomly divided into 6 groups $(\mathrm{n}=$ 10): negative control, positive control, kaempferol, quercetin, kaempferol-3-O- $\beta$-Dglucose and quercetin-3-O- $\beta$-D-glucose groups. Fluoxetine, kaempferol, quercetin, kaempferol-3$O-\beta$-D-glucose and quercetin-3-O- $\beta$-D-glucose were separately dissolved in $0.5 \%$ CMC-Na to obtain $2 \mathrm{mM}$ fluoxetine, $35 \mathrm{mM}$ kaempferol, 35 $\mathrm{mM}$ quercetin, $35 \mathrm{mM}$ kaempferol-3-O- $\beta$-Dglucose and $35 \mathrm{mM}$ quercetin-3-O- $\beta$-D-glucose. The vehicle solvent ( $0.5 \%$ CMC-Na) and fluoxetine served as negative control and positive control groups, respectively. The doses of fluoxetine, kaempferol, quercetin, kaempferol-3$O-\beta$-D-glucose and quercetin-3-O- $\beta$-D-glucose for mouse were $0.2,0.35,0.35,0.35$ and 0.35 $\mathrm{mM} / \mathrm{kg}$, respectively. The vehicle and drugs were intraperitoneally administered at volume of 0.1 $\mathrm{mL} / 10 \mathrm{~g} 60 \mathrm{~min}$ prior to the test session. 
<smiles>O=c1c(O)c(-c2ccc(O)cc2)oc2cc(O)cc(O)c12</smiles><smiles>CCOc1c(-c2ccc(O)cc2)oc2cc(O)cc(O)c2c1=O</smiles><smiles>CCOc1c(-c2ccc(O)c(O)c2)oc2cc(O)cc(O)c2c1=O</smiles>

Figure 1: Chemical structure of kaempferol (1), quercetin (2), kaempferol-3-O- $\beta-D-g l u c o s e ~(3)$ and quercetin-3O- $\beta$-D-glucose (4); polarity: $1<2<3<4$

\section{Forced swimming test (FST)}

FST was carried out on mice according to the existing method with some modifications $[18,20,21]$. Mice were individually placed into glass cylinders (height $25 \mathrm{~cm}$, diameter $10 \mathrm{~cm}$ ), which were filled with water (temperature: $25 \pm 1$ ${ }^{\circ} \mathrm{C}$; depth: $18 \mathrm{~cm}$ ). Twenty-four hours after the pretest, mice were forced to swim in the glass cylinders for $6 \mathrm{~min}$. After $2 \mathrm{~min}$ swimming, the duration of immobility was recorded during the remaining $4 \mathrm{~min}$ using a video camera. Mice were judged to be immobile when no additional activity was observed other than that those movements necessary to keep its head above the water. Additionally, the observer recording the immobility of mice was blinded to the drug treatments and after each test, the glass cylinders was refilled with fresh water.

\section{Tail suspension test (TST)}

TST was carried out on mice according to the existing method with some modifications [22]. Briefly, each mouse was individually suspended by the tail $(20 \mathrm{~mm}$ from the end) for $6 \mathrm{~min}$ in a box $\left(250 \times 250 \times 300 \mathrm{~mm}^{3}\right)$ with the head $50 \mathrm{~mm}$ from the bottom. Testing was carried out in a darkened room with minimal background noise. The duration of immobility was recorded during the final $4 \mathrm{~min}$ of the test using a video camera. Mice were judged to be immobile only when they were passively hanged and completely motionless. Additionally, the observer recording the immobility of mice was blinded to the drug treatments.

\section{Locomotor activity test (LAT)}

To access the effects of drugs on locomotor activity, mice were individually placed into cylinders (height $25 \mathrm{~cm}$, diameter $15 \mathrm{~cm}$ ) at the same time $60 \mathrm{~min}$ after drug administration and then the total locomotor activity of each mouse was automatically measured and recorded in 5 min separately by an activity-monitoring system (Institute of Materia Medica, Chinese Academy of Medical Sciences) [1].

\section{Determination of monoamine neurotransmitter and metabolite}

The neurotransmitter concentrations in mice brain were simultaneously determined according to the existing method with some modifications [23]. The vehicle group (negative control group) without any stress was added as vehicle-stress group in this part. After the FST and TST were completed, mice were sacrificed by decapitation in the animal laboratory, and their brain tissues were immediately obtained on ice and stored at $80^{\circ} \mathrm{C}$ until biochemistry assay. The brain tissue of each mouse was homogenized in ice-cold $0.02 \mathrm{M}$ perchloric acid including 1.0 $\mu \mathrm{M}$ DHBA (internal standard). Then the homogenates were centrifuged at $14000 \mathrm{rpm}$ for $15 \mathrm{~min}$ at $4^{\circ} \mathrm{C}$, and the supernatant was separated and filtered through a $0.22 \mu \mathrm{m}$ membrane filter prior to HPLC analysis. The HPLC analysis was carried out on Agilent 1200 (Ageilent, USA), equipped with ECD (Model 5300A CoulArray Detector) and connected to an Agilent ChemStation. The chromatography was performed on a Diamonil 
C18 column (4.6 $\mathrm{mm} \times 25 \mathrm{~mm}, 5 \mu \mathrm{m})$. The mobile phase consisted of $11 \%$ methanol and 0.1 $\mathrm{M} \mathrm{NaH} 2 \mathrm{PO} 4$ aqueous solution including $0.5 \mathrm{mM}$ EDTA $\cdot \mathrm{Na}_{2}$ and $0.85 \mathrm{mM}$ OSA. The $\mathrm{pH}$ of mobile phase was adjusted to 3.4 using phosphate acid. Then mobile phase were filtered through $0.22 \mu \mathrm{m}$ membrane prior to HPLC analysis. The flow rate, injection volume, column temperature and working potential were $0.8 \mathrm{~mL} / \mathrm{min}, 20 \mu \mathrm{L}, 25^{\circ} \mathrm{C}$ and $+80 \mathrm{mV}$, respectively. The quantifications of $\mathrm{NE}$, DA, 5-HT and 5-HIAA in sample were analyzed by standard curve method. Additionally, the levels of NE, DA, 5-HT and 5-HIAA were represented as $\mathrm{ng} / \mathrm{g}$ per brain wet weight.

\section{Statistical analysis}

All data are presented as mean \pm standard error of the mean (SEM, $n=10$ ). One-way ANOVA (LSD test) was used to analyze differences among different groups on SPSS (version 20.0). Differences were recognized as statistically significant at $p<0.05$.

\section{RESULTS}

\section{Effects of four flavonoids on duration of immobility}

As shown in Figures 2 and 3, after treatment with fluoxetine at dose of $0.2 \mathrm{mM} / \mathrm{kg}$, the duration of immobility (58.9 and $38.59 \mathrm{sec}$ ) in FST and TST was significantly $(p<0.05)$ reduced, compared with the vehicle group (146.18 and $126.18 \mathrm{sec}$ ), and the results indicated that the FST and TST models were successfully established. After treatment with kaempferol, quercetin, kaempferol-3-O- $\beta$-D-glucose or quercetin-3-O- $\beta$ D-glucose at dose of $0.35 \mathrm{mM} / \mathrm{kg}$, the duration of immobility (72.58 - 90.24 and 52.58 - $70.24 \mathrm{sec})$ was significantly $(p<0.05)$ reduced in FST and TST, compared with the vehicle group (146.18 and $126.18 \mathrm{sec}$ ). Moreover, the inhibitory effects of the four flavonoids on the duration of immobility in FST and TST were significantly $(p<$ 0.05) different (kaempferol < quercetin < kaempferol-3-O- $\beta$-D-glucose < quercetin-3-O- $\beta$ D-glucose).

\section{Effects of four flavonoids on locomotor activity}

As shown in Figure 4, the locomotor activity counts did not show any significant differences among the vehicle, fluoxetin, kaempferol, quercetin, kaempferol-3-O- $\beta$-D-glucose and quercetin-3-O- $\beta-D$-glucose groups. The results suggested that the effects of drug treatments on the reductions of immobility time in FST and TST were not induced by possible CNS-stimulating effects.

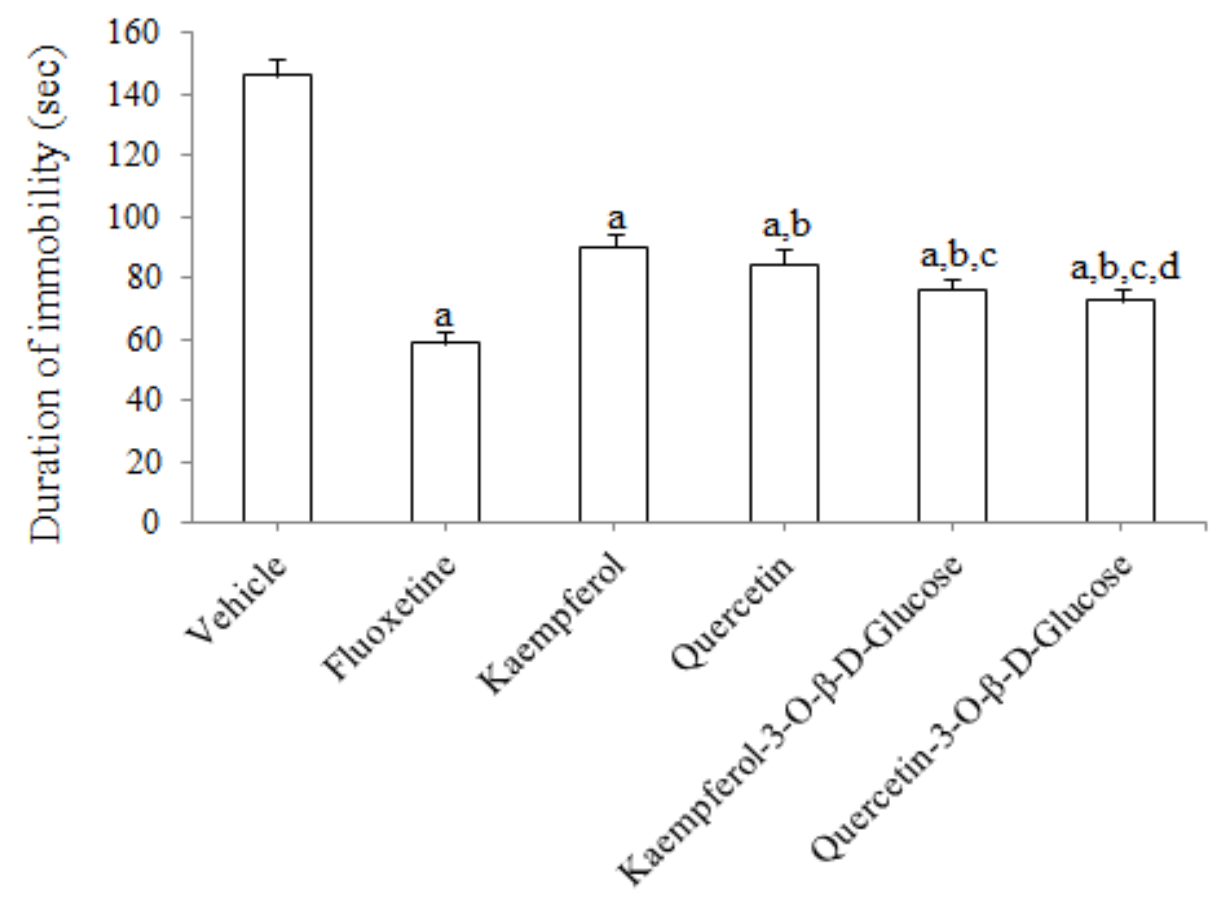

Figure 2: Effects of kaempferol, quercetin, kaempferol-3-O- $\beta$-D-glucose and quercetin-3-O- $\beta$-D-glucose on the duration of immobility in FST; ${ }^{a} p<0.05$ vs. the vehicle group, ${ }^{b} p<0.05$ vs. the kaempferol group, ${ }^{c} p<0.05$ vs. the quercetin group, ${ }^{d} p<0.05$ vs. the kaempferol-3-O- $\beta$-D-glucose group 


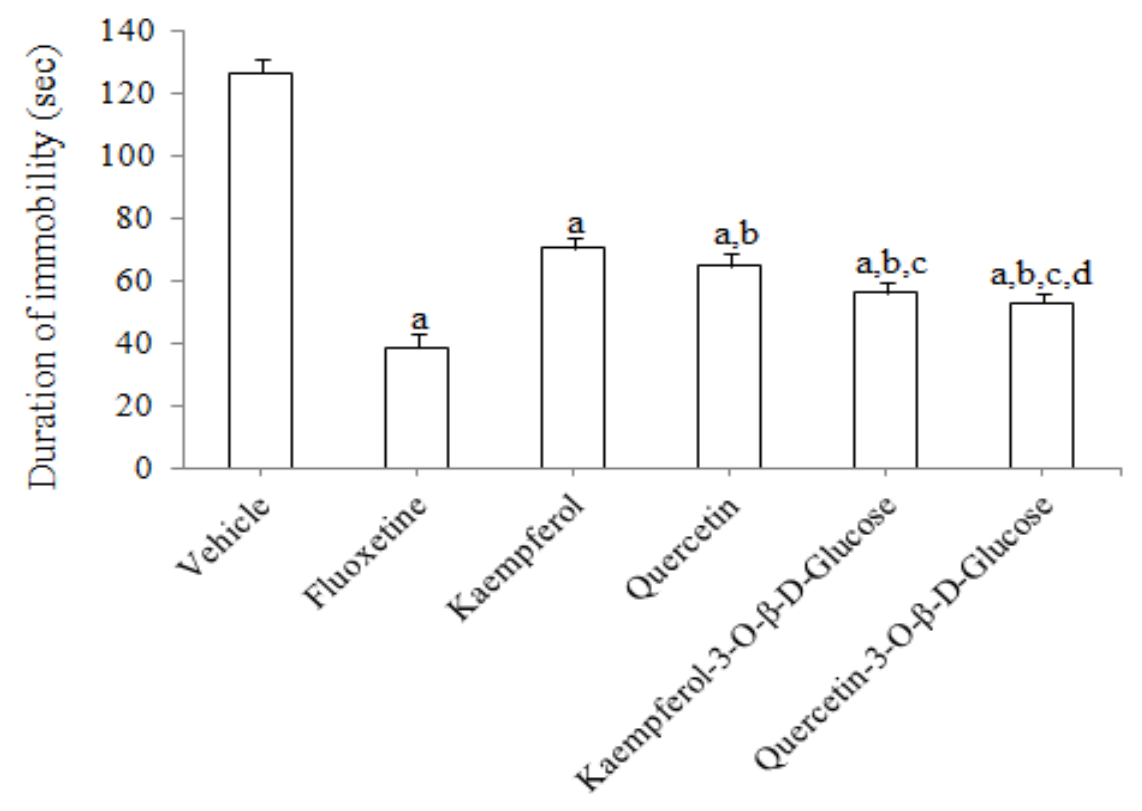

Figure 3: Effects of kaempferol, quercetin, kaempferol-3-O- $\beta$-D-glucose and quercetin-3-O- $\beta$-D-glucose on the duration of immobility in TST; ${ }^{a} p<0.05$ vs. the vehicle group, ${ }^{b} p<0.05$ vs. the kaempferol group, ${ }^{c} p<0.05$ vs. the quercetin group, ${ }^{d} p<0.05$ vs. the kaempferol-3-O- $\beta$-D-glucose group

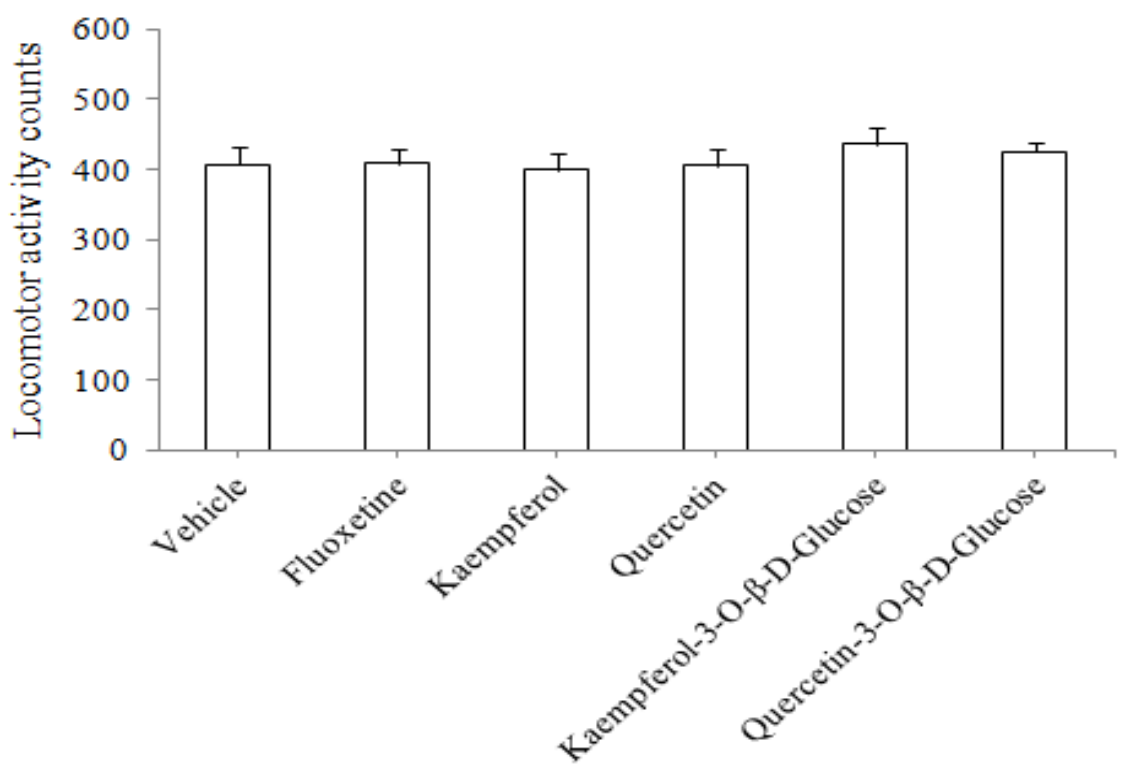

Figure 4: Effects of kaempferol, quercetin, kaempferol-3-O- $\beta$-D-glucose and quercetin-3-O- $\beta$-D-glucose on locomotor activity of mice

\section{Effect of four flavonoids on monoamine neurotransmitter and metabolite}

The quantifications of monoamine neurotransmitter and metabolite concentrations in sample were evaluated according to the standard curves of NE $(y=0.045800 x+0.003712$, $r=0.9999)$, DA $\quad(y=0.054806 x+0.006300$, $r=0.9998), \quad 5-\mathrm{HT} \quad(\mathrm{y}=0.048102 x+0.001102$, $r=0.9994)$ and 5-HIAA $(y=0.050893 x+0.004106$, $r=0.9999)$. The chromatogram of standard substances and sample are shown in Figure 5.
The effects of drug treatments on the levels of NE, DA, 5-HT and 5-HIAA in FST and TST are presented in Tables 1 and 2 . The effects of drug treatments on the ratio of $5-\mathrm{HIAA} / 5-\mathrm{HT}$ in FST and TST are shown in Figures 6 and 7 . Compared with the vehicle-stress group, the levels of NE, DA, 5-HT of vehicle group were significantly $(p<0.05)$ reduced in FST and TST, and the level of 5-HIAA and the ratio of 5HIAA/5-HT of vehicle group were significantly ( $p$ $<0.05$ ) increased in FST and TST. After treatment with fluoxetin at dose of $0.2 \mathrm{mM} / \mathrm{kg}$, the 
levels of NE, DA and 5-HT were significantly $(p<$ 0.05 ) increased in FST and TST, compared with the vehicle group, and the level of 5-HIAA and the ratios of $5-\mathrm{HIAA} / 5-\mathrm{HT}$ were significantly $(p<$ 0.05) reduced in FST and TST, compared with the vehicle group. The results of the vehiclestress, vehicle and fluoxetin groups indicated that the FST and TST models were successfully established. After treatment with kaempferol, quercetin, kaempferol-3-O- $\beta$-D-Glucose or quercetin-3-O- $\beta$-D-glucose at dose of 0.35 $\mathrm{mM} / \mathrm{kg}$, the levels of $\mathrm{NE}, \mathrm{DA}$ and $5-\mathrm{HT}$ were significantly $(p<0.05)$ increased in FST and TST, compared with the vehicle group, and the level of 5-HIAA and the ratios of 5-HIAA/5-HT were significantly $(p<0.05)$ reduced in FST and TST, compared with the vehicle group. Moreover, the reversed effects of the four flavonoids on the levels of NE, DA, 5-HT and 5HIAA and the ratio of 5-HIAA/5-HT were significantly $(p<0.05)$ different in FST and TST (kaempferol < quercetin < kaempferol-3-O- $\beta$-Dglucose < quercetin-3-O- $\beta$-D-glucose).

Table 1: Effects of kaempferol, quercetin, kaempferol-3-O- $\beta$-D-glucose and quercetin-3-O- $\beta$-D-glucose on the levels of NE, DA, 5-HT and 5-HIAA in FST

\begin{tabular}{|c|c|c|c|c|}
\hline Group & $\mathrm{NE}(\mathrm{ng} / \mathrm{g})$ & $\mathrm{DA}(\mathrm{ng} / \mathrm{g})$ & 5-HT (ng/g) & 5-HIAA (ng/g) \\
\hline Vehicle & $138.4 \pm 9.8$ & $235.4 \pm 43.1$ & $183.4 \pm 12.4$ & $1363.4 \pm 47.2$ \\
\hline Fluoxetine & $463.2 \pm 24.9^{a}$ & $640.1 \pm 52.8^{a}$ & $479.3 \pm 4.7^{a}$ & $835.5 \pm 45.6^{\mathrm{a}}$ \\
\hline Kaempferol & $238.7 \pm 35.6^{\mathrm{a}}$ & $308.4 \pm 34.2^{a}$ & $261.4 \pm 20.4^{\mathrm{a}}$ & $1244.7 \pm 41.2^{\mathrm{a}}$ \\
\hline Quercetin & $312.4 \pm 47.1^{\mathrm{a}, \mathrm{b}}$ & $391.0 \pm 23.5^{\mathrm{a}, \mathrm{b}}$ & $387.6 \pm 18.5^{\mathrm{a}, \mathrm{b}}$ & $1128.9 \pm 54.6^{\mathrm{a}, \mathrm{b}}$ \\
\hline Kaempferol-3-O- $\beta$-D-glucose & $358.1 \pm 39.5^{\mathrm{a}, \mathrm{b}, \mathrm{c}}$ & $469.4 \pm 25.7^{\mathrm{a}, \mathrm{b}, \mathrm{c}}$ & $467.2 \pm 30.1^{\mathrm{a}, \mathrm{b}, \mathrm{c}}$ & $1054.4 \pm 54.7^{\mathrm{a}, \mathrm{b}, \mathrm{c}}$ \\
\hline Quercetin-3-O- $\beta$-D-glucose & $405.7 \pm 41.2^{\mathrm{a}, \mathrm{b}, \mathrm{c}, \mathrm{d}}$ & $528.1 \pm 23.8^{\mathrm{a}, \mathrm{b}, \mathrm{c}, \mathrm{d}}$ & $531.9 \pm 25.7^{\mathrm{a}, \mathrm{b}, \mathrm{c}, \mathrm{d}}$ & $940.8 \pm 50.3^{\mathrm{a}, \mathrm{b}, \mathrm{c}, \mathrm{d}}$ \\
\hline Vehicle-stress & $512.4 \pm 30.2^{a}$ & $654.8 \pm 34.7^{\mathrm{a}}$ & $645.7 \pm 52.4^{\mathrm{a}}$ & $808.9 \pm 32.1^{\mathrm{a}}$ \\
\hline
\end{tabular}

${ }^{a} p<0.05$ vs. the vehicle group, ${ }^{b} p<0.05$ vs. the kaempferol group, ${ }^{c} p<0.05$ vs. the quercetin group, ${ }^{d} p<0.05$ vs. the kaempferol-3-O- $\beta$-D-glucose group

Table 2: Effects of kaempferol, quercetin, kaempferol-3-O- $\beta$-D-glucose and quercetin-3-O- $\beta$-D-glucose on the levels of NE, DA, 5-HT and 5-HIAA in TST

\begin{tabular}{|c|c|c|c|c|}
\hline Group & $\mathrm{NE}(\mathrm{ng} / \mathrm{g})$ & $\mathrm{DA}(\mathrm{ng} / \mathrm{g})$ & $5-\mathrm{HT}(\mathrm{ng} / \mathrm{g})$ & 5-HIAA (ng/g) \\
\hline Vehicle & $143.7 \pm 11.2$ & $218.6 \pm 32.5$ & $201.4 \pm 23.7$ & $1240.9 \pm 56.3$ \\
\hline Fluoxetine & $441.8 \pm 19.4^{a}$ & $596.1 \pm 46.7^{\mathrm{a}}$ & $498.5 \pm 34.1^{a}$ & $838.5 \pm 38.9^{a}$ \\
\hline Kaempferol & $243.9 \pm 26.1^{\mathrm{a}}$ & $296.7 \pm 26.1^{a}$ & $279.8 \pm 23.2^{\mathrm{a}}$ & $1164.1 \pm 58.2^{\mathrm{a}}$ \\
\hline Quercetin & $298.4 \pm 37.5^{\mathrm{a}, \mathrm{b}}$ & $388.6 \pm 30.3^{\mathrm{a}, \mathrm{b}}$ & $321.3 \pm 29.5^{\mathrm{a}, \mathrm{b}}$ & $1040.9 \pm 45.7^{\mathrm{a}, \mathrm{b}}$ \\
\hline Kaempferol-3-O- $\beta$-D-glucose & $368.7 \pm 20.2^{a, b, c}$ & $473.1 \pm 31.2^{\mathrm{a}, \mathrm{b}, \mathrm{c}}$ & $391.6 \pm 38.6^{\mathrm{a}, \mathrm{b}, \mathrm{c}}$ & $962.4 \pm 40.1^{\mathrm{a}, \mathrm{b}, \mathrm{c}}$ \\
\hline Quercetin-3-O- $\beta$-D-glucose & $423.6 \pm 28.8^{\mathrm{a}, \mathrm{b}, \mathrm{c}, \mathrm{a}}$ & $534.9 \pm 35.3^{\mathrm{a}, \mathrm{b}, \mathrm{c}, \mathrm{d}}$ & $481.4 \pm 45.5^{\mathrm{a}, \mathrm{b}, \mathrm{c}, \mathrm{a}}$ & $880.8 \pm 39.3^{\mathrm{a}, \mathrm{b}, \mathrm{c}, \mathrm{d}}$ \\
\hline Vehicle-stress & $512.4 \pm 30.2^{a}$ & $637.5 \pm 54.6^{a}$ & $645.7 \pm 52.4^{\mathrm{a}}$ & $897.9 \pm 52.1^{\mathrm{a}}$ \\
\hline
\end{tabular}

${ }^{a} p<0.05$ vs. the vehicle group, ${ }^{b} p<0.05$ vs. the kaempferol group, ${ }^{c} p<0.05$ vs. the quercetin group, ${ }^{d} p<0.05$ vs. the kaempferol-3-O- $\beta$-D-glucose group

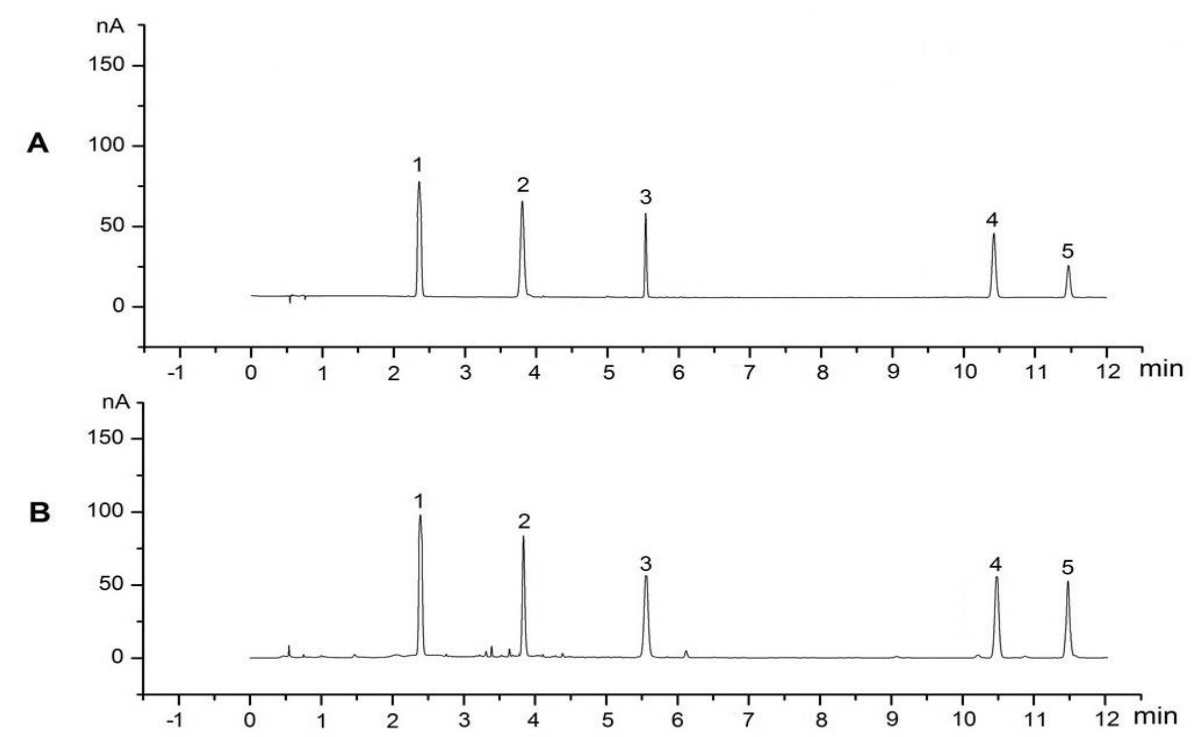

Figure 5: Chromatogram of standard substances (A) and sample (B); peak 1: NE, 2: DHBA, 3: DA, 4: 5-HT, 5: 5HIAA 


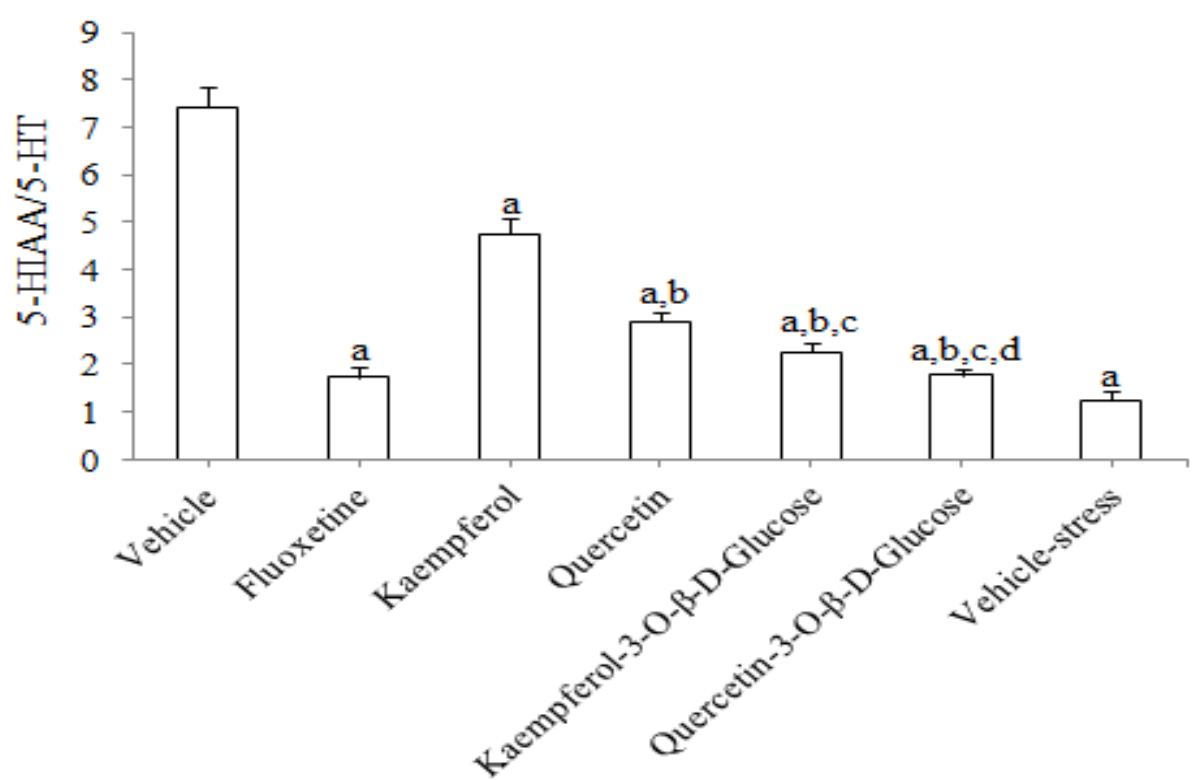

Figure 6: Effects of kaempferol, quercetin, kaempferol-3-O- $\beta$-D-glucose and quercetin-3-O- $\beta$-D-glucose on the ratio of 5 -HIAA/5-HT in FST; ${ }^{a} p<0.05$ vs. the vehicle group, ${ }^{b} p<0.05$ vs. the kaempferol group, ${ }^{c} p<0.05$ vs. the quercetin group, ${ }^{d} p<0.05$ vs. the kaempferol-3-O- $\beta$-D-glucose group

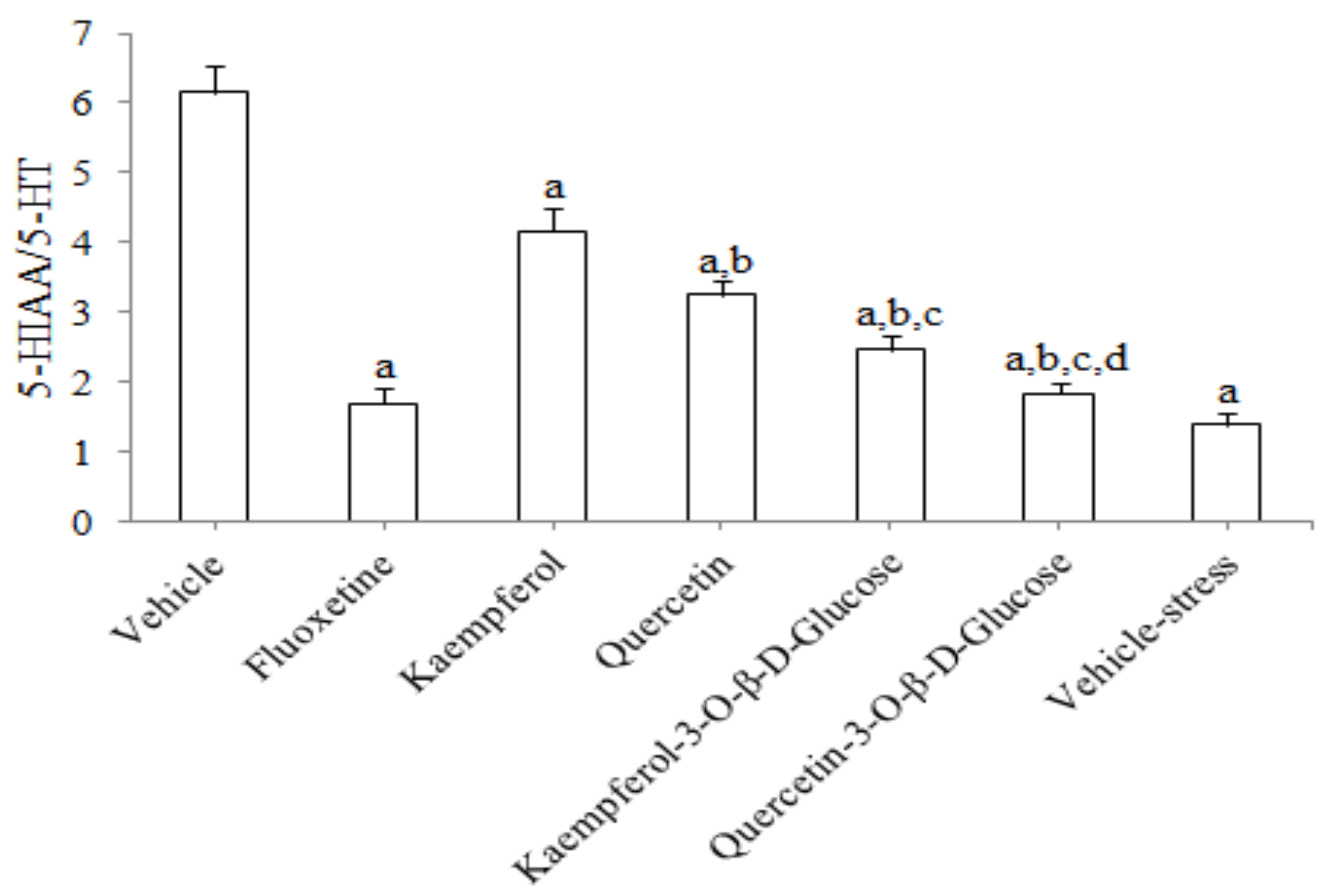

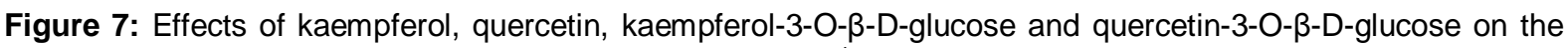
ratio of 5 -HIAA/5-HT in TST; ${ }^{a} p<0.05$ vs. the vehicle group, ${ }^{b} p<0.05$ vs. the kaempferol group, ${ }^{c} p<0.05$ vs. the quercetin group, ${ }^{d} p<0.05$ vs. the kaempferol-3-O- $\beta$-D-glucose groupffects of kaempferol, quercetin, kaempferol$3-O-\beta-D-g l u c o s e$ and quercetin-3-O- $\beta$-D-glucose on locomotor activity of mice

\section{DISCUSSION}

In the present study, the differences of antidepressant activities of quercetin, quercetin-3-O$\beta$-D-glucose, kaempferol, kaempferol-3-O- $\beta$-Dglucose from $A$. venetum leaf and the possible mechanisms were investigated by FST, TST and LAT.
The FST and TST are two accepted stress models used to evaluate the anti-depressant activities of drugs $[1,24]$. If a drug can induce the locomotor activity, a false positive activity in FST and TST will be observed and thus LAT should be carried out to rule out the false positive activity [25]. As shown in Figures 2 - 4, the results of FST, TST and LAT indicated that kaempferol, quercetin, kaempferol-3-O- $\beta-D-$ 
glucose and quercetin-3-O- $\beta$-D-glucose had significant anti-depressant activity by reducing the immobility time of mice, and the inhibitory effects of the four flavonoids on the immobility time were positively related to their polarity.

The monoamine theory is a widely admitted explanation for depression, which can lead to the impairment of monoaminergic functions and reduce the levels of monoamine neurotransmitters (NE, DA and 5-HT) [26]. The symptom of depression can be alleviated by upregulating the levels of monoamine neurotransmitters (NE, DA and $5-\mathrm{HT}$ ) in the CNS [27]. The tricyclic antidepressants, monoamine oxidase inhibitors and selective 5-HT reuptake inhibitors are now widely used in the clinic, and fluoxetine, a kind of selective 5-HT reuptake inhibitor, are more popular because of its lower toxicity $[28,29]$. So, the fluoxetine was selected as the positive control in the study. The ratio of neurotransmitter/its metabolite can be considered as an index of neurotransmitter metabolism, and the reduction of the ration indicates the reduction of neurotransmitter metabolism [29,30]. As shown in Tables 1 and 2 and Figures 6 and 7, kaempferol, quercetin, kaempferol-3-O- $\beta$-D-glucose and quercetin-3-O$\beta$-D-glucose significantly increased the levels of $\mathrm{NE}, \mathrm{DA}$ and $5-\mathrm{HT}$ and reduced the levels of 5HIAA and the ratio of 5-HIAA/5-HT in the mice brain of FST and TST. Namely, their possible mechanisms of anti-depressant activity were related to the increase of NE, DA and $5-\mathrm{HT}$ as well as reduction of $5-\mathrm{HT}$ metabolism in mice brain. Moreover, the reversed effects of the four flavonoids on the levels of NE, DA, 5-HT and 5HT metabolism were positively related to their polarity.

\section{CONCLUSION}

Kaempferol, quercetin, kaempferol-3-O- $\beta$-Dglucose and quercetin-3-O- $\beta-D-g l u c o s e$ from $A$. venetum leaf have significant anti-depressant activity that is positively related to their polarity. The mechanism may be related to the increase of NE, DA and 5-HT as well as reduction of $5-\mathrm{HT}$ metabolism. The study provides the evidence to support that $A$. venetum leaf has anti-depressant activity and the reference for studying the structure-function relationship of flavonoids on anti-depressant activity.

\section{ACKNOWLEDGEMENT}

This study was supported by Beijing Traditional Chinese Medicine Science and Technology Development Fund (no. JJ2013-08) and Project of Beijing Institute of Integrated Chinese and Western Medicine (no. Psychiatry 2013).

\section{REFERENCES}

1. Wang WX, Hu XY, Zhiyu Zhao, Liu P, Hu YC, Zhou JP, Zhou DF, Wang ZB, Guo D, Guo HZ. Antidepressantlike effects of liquiritin and isoliquiritin from Glycyrrhiza uralensis in the forced swimming test and tail suspension test in mice. Prog NeuroPsychopharmacol Biol Psychiatry 2008; 32: 11791184.

2. Murray CJL, Lopez AD. The global burden of disease. Cambridge: Harvard Univ Press 1996; p. 21.

3. Zhang WM, Xiao ZC, Gu GP, Zhang GL, Qian XS. On the resources utilization of Apocynum and its classification. Chin Wild Plant Resour 2006; 25(2): 15-19.

4. Cao $Y$, Chu $Q$, Ye J. Determination of hydroxyl radical by capillary electrophoresis and studies on hydroxyl radical scavenging activities of Chinese herbs. Anal. Bioanal. Chem. 2003; 376(5): 691-695.

5. Shirai M, Kawai Y, Yamanishi R, Terao J. Approach to novel functional foods for stress control 5. Antioxidant activity profiles of antidepressant herbs and their active component. 2005; 52: 249-251.

6. Kim DW, Yokozawa T, Hattori M, Kadota $S$ and Namba $T$. Effects of aqueous extract of Apocynum venetum leaves on spontaneously hypertensive, renal hypertensive and $\mathrm{NaCl}$-fed-hypertensive rats. $J$ Ethnopharmacol 2000; 72(1-2): 53-59.

7. Butterweck V, Nishibe S, Sasaki T, Uchida $M$. Antidepressant effects of Apocynum venetum leaves in a forced swimming test. Biol Pharm Bull 2001; 24: 848-851.

8. Grundmann O, Nakajima JL, Seo S, Butterweck V. Antianxiety effects of Apocynum venetum $L$. in the elevated plus maze test. J Ethnopharmacol 2007; 110(3): 406-411.

9. Zhou BH, Feng $Q$, Li XJ, Wang HY, Liu M, Huang FW, Wang $\mathrm{CH}$, $\mathrm{Hu} X \mathrm{X}$. Screening of antidepressant fractions of the leaves of Apocynum Venetum $L$.. China Pharm 2007; 10(12): 1173-1175.

10. Zheng MZ, Fan YJ, Xiu J, Shi DF, Liu CM. Studies on the antidepressant-like effects and 5-HT mechanisms of flavonoids extracted from Apocynum venetum leaves. Liaoning J Trad Chin Med 2012; 39(5): 935-937.

11. Zheng $M Z$, Shi DF, Fan YJ, Liu CM. Study on the antidepressant-like effect and NE mechanisms of flavonoids extracted from Apocynum venetum leaves. Guangdong Agr Sci 2012; (16): 169-171.

12. Zheng $M Z$, Wu SL, Shi DF, Liu CM. Antidepressive-like effects of total flavonoids from Apocynum venetum leaves and their mechanisms. China Trad Herb Drugs 2012; 43(12): 2468-2470.

13. Zheng $M Z$, Liu CM, Cong $D L$, Shi DF, Zhang $Y C, W u$ GM. Accelerating expression of antidepressant effect associate-gene CREB and BDNF of flavonoids

Trop J Pharm Res, December 2015; 14(12): 2276 
extraxt content from Apocynum venetum leaves. Genomics Appl Biol 2011; 30(2): 184-189.

14. Zheng MZ, Liu CM, Hu W, Shi DF, Zhang YC, Wu GM. Antidepressant effect of flavonoid extract from Apocynum venetum leaves in mice. Lishizhen Med Mater Med Res 2011; 22(10): 2319-2321.

15. Li LH, Yuan Z. Study on flavonoids in leaves of Apocynum ventum. China J Chin Mater Med 2006; 31(16): 1337-1340.

16. Cheng XL, Zhang SQ, Li QS. Chemical constituents of flavonoids from Apocynum venetum. J Chin Med Mater 2007; 30(9): 1086-1088.

17. Anjaneyulu M, Chopra K, Kaur Indupal. Antidepressant activity of quercetin, a bioflavonoid, in streptozotocininduced diabetic mice. J Med Food 2003; 6(4): 391 395.

18. Hosseinzadeh $H$, Motamedshariaty V, Hadizadeh $F$. Antidepressant effect of kaempferol, a constituent of saffron (Crocus sativus) petal, in mice and rats. Pharmacologyonline 2007; 2: 367-370.

19. The National Research Council of The National Academy of Sciencies. Guide for the Care and Use of Laboratory Animals: Eight Edition. Washington, D.C.: The National Academies Press; 2010.

20. Porsolt RD, Bertin A, Jalfre M. Behavioural despair in mice: a primary screening test for antidepressants. Arch Int Pharmacodyn Ther 1977; 229: 327-336.

21. Kageyama A, Ueno $T$, Oshio M, Masuda $H$, Horiuchi $H$, Yokogoshi $H$. Antidepressant-like effects of an aqueous extract of lavender (Lavandula angustifolia Mill.) in rats. Food Sci Technol Res 2012; 18(3): 473479.

22. Steru L, Chermat R, Thierry B, Simon $P$. The tail suspension test: a new method for screening antidepressants in mice. Psychopharmacology 1985; 85: 367-370.

23. Pen GH, Tan Y, Zeng LM. Simultaneous determination of catecholamine levels in plasma by high performance liquid chromatography. Bull Hunan Med Univ 2001; 26:485-487.

24. Zheng MZ, Fan YJ, Shi DF, Liu CM. Antidepressant-like effect of flavonoids extracted from Apocynum venetum leaves on brain monoamine leaves and dopaminergic system. J Ethnopharmacol 2013; 147: 108-113.

25. Yi LT, Li CF, Zhan X, Cui CC, Xiao F, Zhou LP, Xie Y. Involvement of monoaminergic system in the antidepressant-like effect of the flavonoid naringenin in mice. Prog Neuro-Psychopharmacol Biol Psychiatry 2010; 34: 1223-1228.

26. Delgado PL. Depression: the case for a monoamine deficiency. J Clin Psychiatry 2000; 61: 7-11.

27. Poirier MF, Boyer P. Venlafaxine and paroxetine in treatment-resistant depression. Double-blind, randomized comparison. Br J Psychiatry 1999; 175: $12-16$.

28. Wong DT, Bymaster FP, Engleman EA. Minireview Prozac (Fluxetine, Lilly 110140), the first selective serotonin uptake inhibitor and an antidepressant drug: twenty years since its first publication. Life Sci 1995; 57: 411-441.

29. Commissing W. Monoamine metabolites: their relationship and lack of relationship to monoaminergic neuronal activity. Biochem Pharmacol 1985; 34: 1127-1131.

30. Schwarting R, Huston J. Behavioral concomitants of regional changes in the brain's biogenic amines after apomorphine and amphetamine. Pharmacol Biochem Behav 1992; 41: 675-682. 